Fifth International Conference on Sustainable Construction Materials and

Technologies. http://www.claisse.info/Proceedings.htm

\title{
SCMT5
}

Kingston University London, UK, July 14-17, 2019

\section{PROPERTIES OF ULTRA-HIGH-PERFORMANCE CONCRETE}

\author{
Ariful Hasnat, M.Sc. ${ }^{1}$, Arash Kian, B.Sc. ${ }^{2}$, Nader Ghafoori Ph. D. ${ }^{3}$
}

${ }^{1}$ PhD student, Department of Civil and Environmental Engineering and Construction, University of Nevada, Las Vegas, NV 89154, USA.

${ }^{2} \mathrm{MSc}$ student, Department of Civil and Environmental Engineering and Construction, University of Nevada, Las Vegas, NV 89154, USA.

${ }^{3}$ Professor, Dep. of Civil and Environmental Engineering and Construction, Univ. of Nevada Las Vegas, NV 89154, USA

\begin{abstract}
In recent years, ultra-high-performance concrete (UHPC) has attracted interest from the research community because of its excellent physical, mechanical, and durability properties. However, due to very high production cost, its application in civil infrastructures has been thus far limited. In this context, an experimental investigation was conducted to produce lower cost UHPC utilizing locally available traditional fine aggregates. In order to obtain the maximum packing density and minimum matrix porosity, uniquely size graded manufactured fine aggregate was produced. Silica fume, industrial and natural pozzolans were used at different replacement levels of cement content. Flow properties, dimensional stability, and compressive and tensile strengths at different ages of the studied UHPCs were evaluated. More than $120 \mathrm{MPa}$ compressive strength was attained using locally available fine aggregate. Fly ash seemed to be more effective than the natural pozzolan in producing higher compressive and tensile strengths. Incorporation of silica fume had positive impact on strength development of the studied UHPCs. However, silica fume increased the drying shrinkage of concrete.
\end{abstract}

Keywords: Industrial pozzolan, natural pozzolan, silica fume, flow, compressive strength, tensile strength.

\section{INTRODUCTION}

Attempts to achieve higher compressive strength have been observed after the development of effective dispersants for cement systems around the 1970s (Wille et al., 2011). Initially known as reactive powder concrete (RPC), now more commonly described as ultra-high-performance concrete (UHPC). It is generally recognized that UHPC exhibits a combination of positive attributes, including very high compressive strength, abridged porosity, high flowability, and better temperature resistance (Sohail et al., 2017). When compared with ordinary cement concrete, UHPC is normally characterized by incorporation of micro-cementitious materials such as silica 
fume to improve particle compactness and pozzolanic reaction, combined with the use of superplasticizer to reduce the water-to-cementitious materials ratio, and higher particle density by using micro sand (Mostofinejad et al. 2016). In addition to exceptionally higher strength properties, UHPC has an ultra-dense microstructure, giving advantageous waterproofing and durability characteristics (Matte \& Moranville, 1999). However, use of these expensive materials significantly increases the production cost which restrains the use of UHPC in the construction industry in a wider scale.

The usage of very high amounts of cement not only affects the production costs, but also has negative effects on the heat of hydration and may cause shrinkage problems (Alsalman et al., 2017). Incorporation of supplementary cementitious materials has the potential to positively affect the durability of concrete and reduce the production cost. For this reason, a number of researches were conducted to replace the cement as well as silica fume with different pozzolanic materials such as fly ash, slag, rice husk ash, and metakaolin. Yalçınkaya and Yazıcı (2017) found that the replacement of $20 \%$ fly ash had minimal effect on the 90-day compressive strength. A significant improvement of microstructure and mechanical properties was found by incorporation of fly ash and it was possible to make concrete with $150 \mathrm{MPa}$ compressive strength by incorporating $30 \%$ of fly ash (Chen et al., 2018). Test results showed that, compressive strength of $200 \mathrm{MPa}$ can be reached with low cement by using high-volume class $C$ fly ash (Yiğiter et al., 2012). The use of Class C fly ash with up to $20 \%$ replacement of cement by weight was found to be beneficial in increasing the compressive strength at later age (28 and 90 days) (Ibrahim et al., 2017). In addition to mechanical and durability properties, fly ash was introduced as a supplemental cementitious material to enhance flowability of the mixture during the mixing stage and large-scale casting (Aghdasi et al., 2016). However, in all these research works, only class C fly ash was utilized. Class F fly ash has not been used for making UHPC.

Fine ground quartz sands are typically used for producing UHPC (Wille et al., 2011). Ground quartz has an average diameter slightly less than the diameter of Portland cement, which enables this material to fill the possible voids between sand, unhydrated cement particles, and the hydration products which creates a denser paste matrix. Conventional concrete sand was used to replace quartz sand and reduce the initial unit cost. Yang et al. (2011) used two types of natural sand to replace ground quartz sand. Experimental results indicated that the use of natural sand led to reduction in compressive strength and fracture energy of about $15 \%$ lower than those of UHPC made with quartz sand. Wang et al. (2012) reported that the 91-days compressive strength could achieve $150 \mathrm{MPa}$ or higher strength when conventional concrete sand was used. In both cases, high-volume silica fume was used, which does not help much in reducing the production cost of UHPC. Alsalman et al., (2017) found that the use of finer sand increases the compressive strength when compared to natural gradation sand, however, this effect is minimal when silica fume is incorporated. In contrast, Ma et al. (2004) concluded that the grain sizes of sand had no significant effect on the concrete's compressive strength. They used two types of sand that had different grain sizes to develop non-fiber reinforced self-compacting UHPC. Zhao et al., (2014) replaced the natural aggregate by the tailings and found compressive strengths of the tailings mixtures 
decreased by less than $11 \%$ while the flexural strengths increased by up to $8 \%$ compared to the control sample with natural sand. An optimum UHPC mixture can be designed with 50\% glass sand replacement of quartz sand. (Soliman \& Tagnit-Hamou, 2017). Meng and Khayat (2017) recommended to use concrete and masonry sand $(70 \%+30 \%)$ as a replacement of quartz sand. However, the size distribution of these mixes was not controlled to achieve the maximum packing density.

No detailed study was conducted on replacing clinker with natural pozzolan and class $\mathrm{F}$ fly ash for producing UHPC using locally available fine aggregates. This study will shed light on the fresh and mechanical properties of UHPC made with cost effective environmentally friendly materials.

\section{EXPERIMENTAL PROGRAM}

\section{Materials}

The experimental program was designed to develop sustainable UHPC by incorporating natural and industrial pozzolanic materials as a partial replacement of cement. The cementitious materials consisted of ASTM C 150 Type V Portland cement (Type V Portland cement is mandated in the western regions of the US), ASTM C 618 natural pozzolan and class F fly ash, and ASTM C 1240 silica fume. Chemical properties of the cement, fly ash, natural pozzolan, and silica fume are presented in Table 1. To achieve the maximum packing density, two types of fine aggregates commonly used in the concrete industry were utilized. The size of the combined fine aggregate varied from $0.075 \mathrm{~mm}$ to $4.75 \mathrm{~mm}$. The gradation of fine aggregate was optimized using the modified Andreasen and Andersen model as shown in Eq. 1.

Table 1: Cementitious material Chemical Compositions

\begin{tabular}{lcccc}
\hline Component & $\begin{array}{c}\text { Type } \mathrm{V} \\
\text { Cement } \\
(\%)\end{array}$ & $\begin{array}{c}\text { Class } \mathrm{F} \\
\text { Fly Ash } \\
(\%)\end{array}$ & $\begin{array}{c}\text { Natural } \\
\text { Pozzolans } \\
(\%)\end{array}$ & $\begin{array}{c}\text { Silica } \\
\text { fume } \\
(\%)\end{array}$ \\
\hline \hline Silicon Dioxide $\left(\mathrm{SiO}_{2}\right)$ & 21 & 59.93 & 68.8 & 94.72 \\
\hline Calcium Oxide $(\mathrm{CaO})$ & 62.4 & 4.67 & 3.2 & - \\
\hline Aluminum Oxide $\left(\mathrm{Al}_{2} \mathrm{O}_{3}\right)$ & 4 & 22.22 & 8.5 & - \\
\hline Ferric Oxide $\left(\mathrm{Fe}_{2} \mathrm{O}_{3}\right)$ & 3.7 & 5.16 & 1.1 & - \\
\hline Magnesium $\mathrm{Oxide}_{2}(\mathrm{MgO})$, & 2.6 & - & - & - \\
\hline Sulfur Trioxide $\left(\mathrm{SO}_{3}\right)$, & 2.2 & 0.38 & - & 0.23 \\
\hline Total Alkali $\left(\mathrm{Na}_{2} \mathrm{O}+\mathrm{K}_{2} \mathrm{O}\right)$ & 0.54 & 1.29 & 6.4 & 0.47 \\
\hline Loss on Ignition $(\mathrm{LOI})$ & 2.0 & 0.32 & 3.7 & 2.82 \\
\hline \hline
\end{tabular}

$$
P(D)=\frac{D^{q}-D_{\min }^{q}}{D_{\max }^{q}-D_{\min }^{q}}
$$


Where, $P(D)$ represents the weight percentage of sand passing the sieve with size $D, D_{\max }$ is the maximum particle size $(\mu \mathrm{m}), D_{\min }$ is the minimum particle size $(\mu \mathrm{m})$, and $q$ is the distribution modulus which is related to the sand particle size. The range of q commonly varies from 0.20 to 0.25 for UHPC. In the studied cases, $\mathrm{q}$ was optimized by conducting relative density testing for $\mathrm{q}=0.21$ to 0.25 at 0.01 interval. The maximum packing density was obtained when $\mathrm{q}=0.21$. The gradation curve for the combined fine aggregates and optimized curve with $q=0.21$ is presented in Figure 1. To ensure the flow properties of UHPC, a carboxylate based high range water reducing admixture (HRWRA) comprising of $44 \%$ solid content was used.

\section{Mixture Design}

A total of five mixture combinations was devised including $100 \%$ cement as control. Twenty percent of cement was replaced with class F fly ash and natural pozzolan, respectively. In addition, two ternary mixtures with $15 \%$ of fly ash and natural pozzolan and $5 \%$ of silica fume were used as a partial replacement of cement. All replacements were calculated volumetrically. Whole fine aggregate to binder $\left(\mathrm{V}_{\mathrm{FA}} / \mathrm{V}_{\mathrm{cm}}\right)$ volumetric ratio commonly varies from 0.80 to 1.2 . For the purpose of this study, $\mathrm{V}_{\mathrm{FA}} / \mathrm{V}_{\mathrm{cm}}$ of 1.0 was used. Table 2 presents the mixture proportion of the studied concretes. A constant water-to-binder $(\mathrm{w} / \mathrm{cm})$ of 0.21 was selected to prepare for the studied concretes. The UHPCs were designed to have a mini-slump flow diameter of $240 \pm 10 \mathrm{~mm}$ by adjusting the HRWR dosage. To achieve the target flow, trial mortars were conducted to determine the required HRWRA.

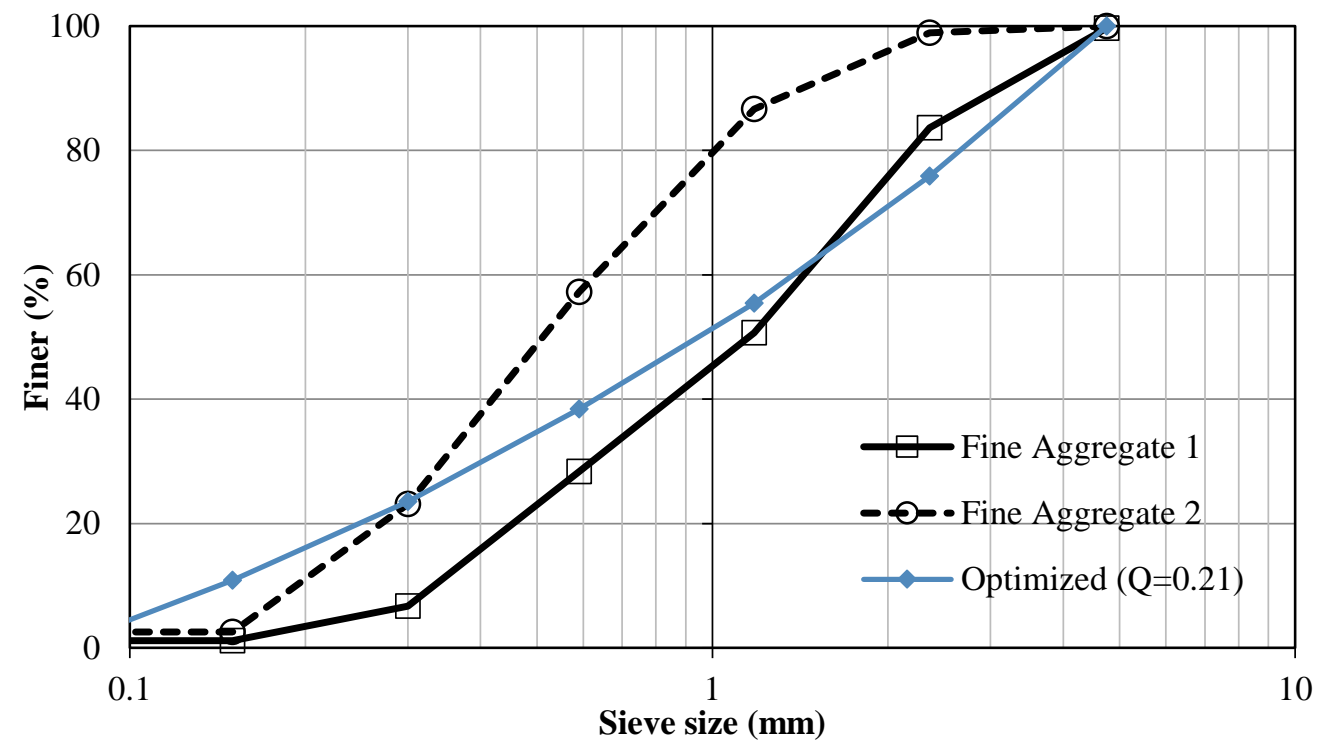

Figure 1: Gradation of fine aggregates

Table 2: Mixture Proportion of UHPCs 
Submission Theme: Efficient and Sustainable Use of Construction Materials

\begin{tabular}{lccccccc}
\hline $\begin{array}{l}\text { Mix } \\
\text { No. }\end{array}$ & $\begin{array}{c}\text { Cement } \\
\left(\mathrm{kg} / \mathrm{m}^{3}\right)\end{array}$ & $\begin{array}{c}\text { Fly Ash } \\
\left(\mathrm{kg} / \mathrm{m}^{3}\right)\end{array}$ & $\begin{array}{c}\text { Natural } \\
\text { Pozzolan } \\
\left(\mathrm{kg} / \mathrm{m}^{3}\right)\end{array}$ & $\begin{array}{c}\text { Silica } \\
\text { Fume } \\
\left(\mathrm{kg} / \mathrm{m}^{3}\right)\end{array}$ & w/cm & $\begin{array}{c}\text { Fine } \\
\text { aggregate } \\
\left(\mathrm{kg} / \mathrm{m}^{3}\right)\end{array}$ & $\begin{array}{c}\text { HRWRA } \\
(\text { Binder \% })\end{array}$ \\
\hline \hline C100 & 1184 & & & & 0.21 & 977 & 1 \\
\hline F20 & 947 & 175 & & & 0.21 & 977 & 0.8 \\
\hline N20 & 947 & & 172 & & 0.21 & 977 & 0.9 \\
\hline F15SF5 & 947 & 131 & & 42 & 0.21 & 977 & 1 \\
\hline N15SF5 & 947 & & 129 & 42 & 0.21 & 977 & 1 \\
\hline \hline
\end{tabular}

\section{Mixing Procedure, Curing, and Test Setup}

The flowchart shown in Figure 2 summarizes the mixing procedures. All the dry cementitious materials were mixed for 5 min at speed of $100 \mathrm{rpm}$ in a Hobert type mixing machine. Then, the fine aggregates were added and mixed for another $5 \mathrm{~min}$. Afterward, $90 \%$ of the water added and mixed for 5-6 min. Finally, the rest of the water and HRWRA were added till uniformity of the paste was observed. The fresh properties of the UHPCs was evaluated through the flowability of the pastes. The flow test was conducted according to ASTM C1437 using a flow table test. The freshly-mixed UHPCs were poured in cylinders, having $50 \mathrm{~mm}$ diameter and 100 $\mathrm{mm}$ height, and kept in the mold for $24 \mathrm{~h}$ in a controlled curing room at $22 \pm 3^{\circ} \mathrm{C}$ and $95 \%$ relative humidity. After $24 \mathrm{~h}$, specimens were demolded and returned to that curing room until test age arrived. Compressive strength was measured after 1 day and 28 days according to the ASTM C 39. Indirect tensile strength and drying shrinkage were evaluated per ASTM C 496, C 157, respectively.

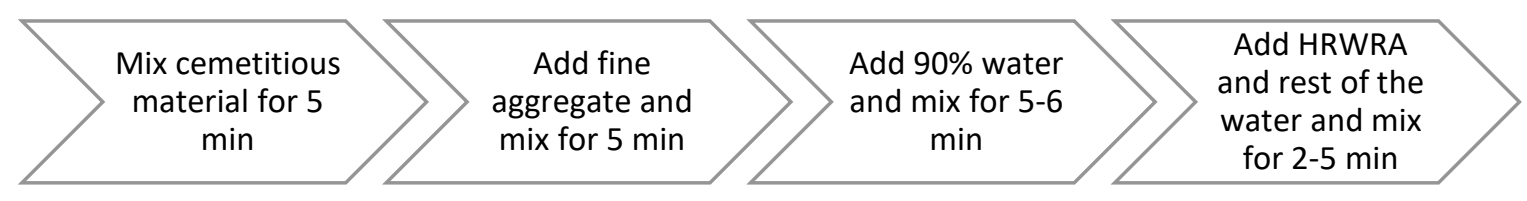

Figure 2: Mixing procedure of UHPCs

\section{RESULTS AND DISCUSSION}

\section{Flow Characteristics}

The flow properties of the studied UHPCs are presented in Figure 3. All studied mixtures complied with the target flow of $240 \pm 10 \mathrm{~mm}$. Replacement of fly ash reduced the HRWRA and showed higher flow diameter amongst the studied UHPCs. Concretes made with silica fume showed comparatively lower flow diameter. The high fineness of silica fume attributed to this outcome. Replacement of the natural pozzolan had no effect on the flow diameter when compared to that of the control. 


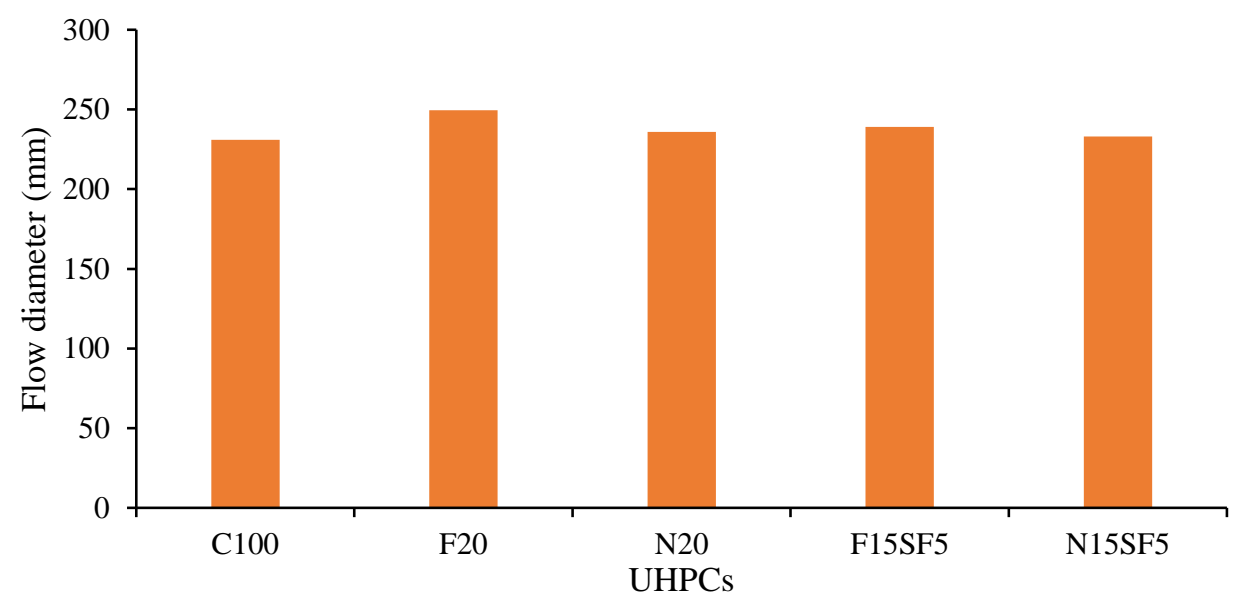

Figure 3: Flow diameter of the fresh UHPCs

\section{Compressive Strength}

Compressive strength of the studied UHPCs after 1 and 28 days is presented in Figure 4. Control UHPC produced higher early strength (1 day) amongst the studied UHPCs (54\% of 28 days compressive strength), whereas fly ash based UHPCs achieved the lowest 1-day strength (44\% and $45 \%$, respectively, of the 28 -day strength). While control concrete attained higher early strength, with the exception of N20, the remainder UHPCs showed higher strength than the control. The concrete with $15 \%$ fly ash and 5\% silica fume, achieved $8 \%$ higher strength than the control concrete (100\% cement). Only $2 \%$ increase in strength observed by the fly ash and silica fume mixture (F15SF5) when compared with the mixture without silica fume (F20). An increase of 7\% compressive strength was obtained in the UHPC containing combined natural pozzolan and silica fume (F15SF5) when compared with the mixture without silica fume (N20). Therefore, replacement of fly ash seems to be more effective than the natural pozzolan in terms of strength development.

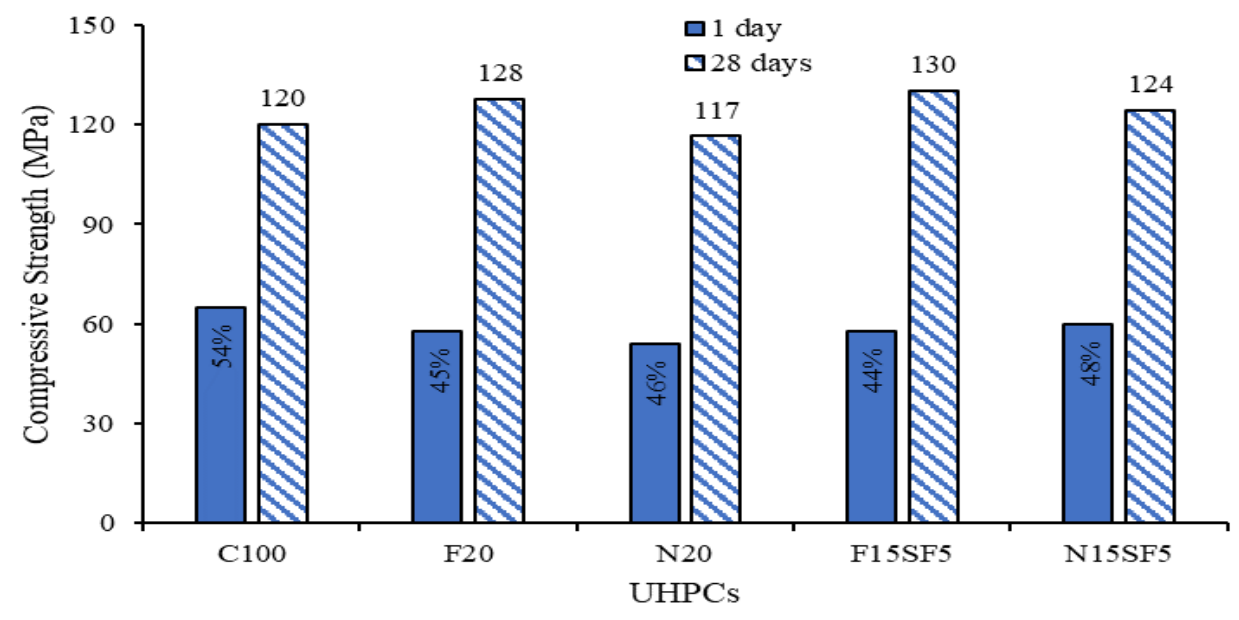

Figure 4: Compressive strength of UHPCs after 1 and 28 days 


\section{Splitting Tensile Strength}

The twenty-eight days splitting tensile strength of the studied UHPCs is presented in Figure 5. Control mixture showed the highest tensile strength, whereas mortar with $20 \%$ natural pozzolan showed the lowest. The UHPC made with 20\% fly ash showed $6 \%$ lower tensile strength than the control mortar. The N20 and N15SF5 produced splitting tensile strengths below that of the control UHPCs by $17 \%$ and $8 \%$, respectively. Figure 6 shows the 28 days compressive to splitting tensile strength ratio for the studied UHPCs. The UHPCs with pozzolanic materials produced 13 to $16 \%$ higher compressive to tensile strength ratio when compared with that of the control UHPC. Mixtures with a longer test period may show better tensile strength performance for the matrix having class $\mathrm{F}$ fly ash and natural pozzolan as stronger concrete impacts tensile strength more than it does compressive strength.

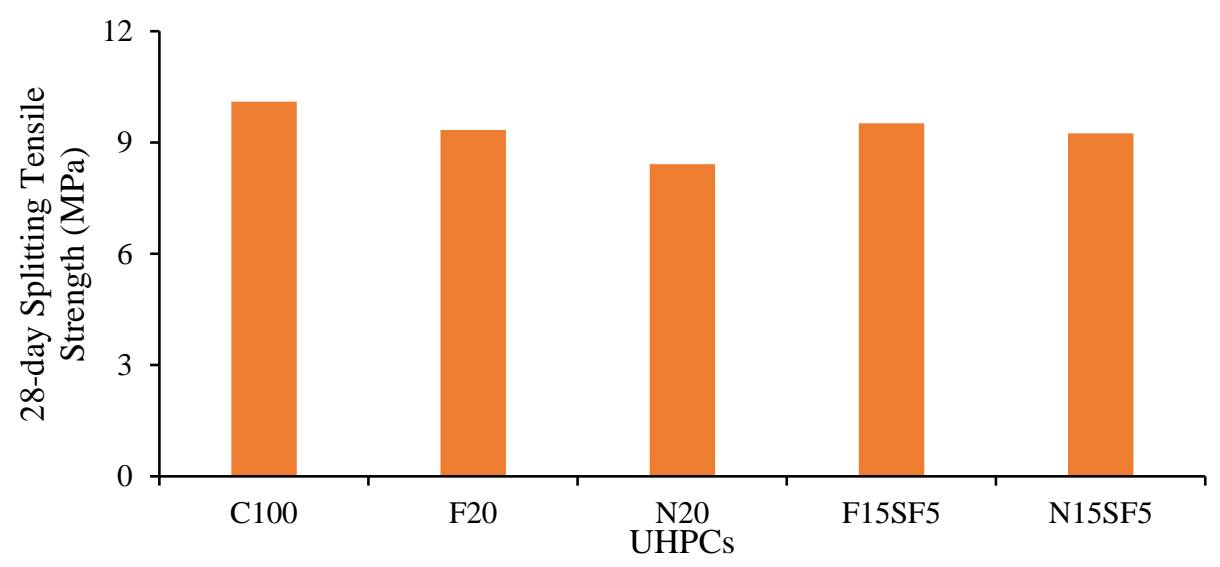

Figure 5: 28-day splitting tensile strength of UHPCs

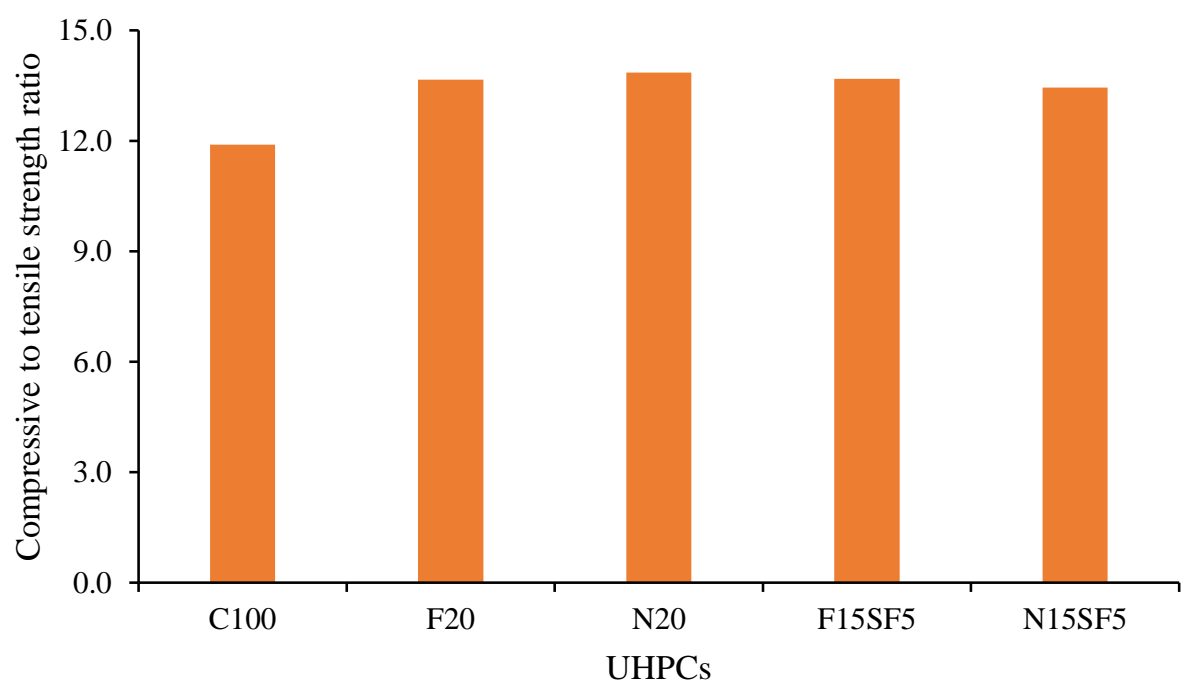

Figure 6: 28-day compressive strength to splitting tensile strength ratio 


\section{Drying Shrinkage}

Figure 7 shows the drying shrinkage of concrete after 14 and 28 days. It can be seen that the UHPCs with fly ash and natural pozzolan produced lower drying shrinkage as compared to that of the control concrete (C100). However, incorporation of silica fume increased the drying shrinkage for both F15SF5 and N15SF5. Amongst the studied UHPCs, natural pozzolan showed best drying shrinkage performance (least dimensional change).

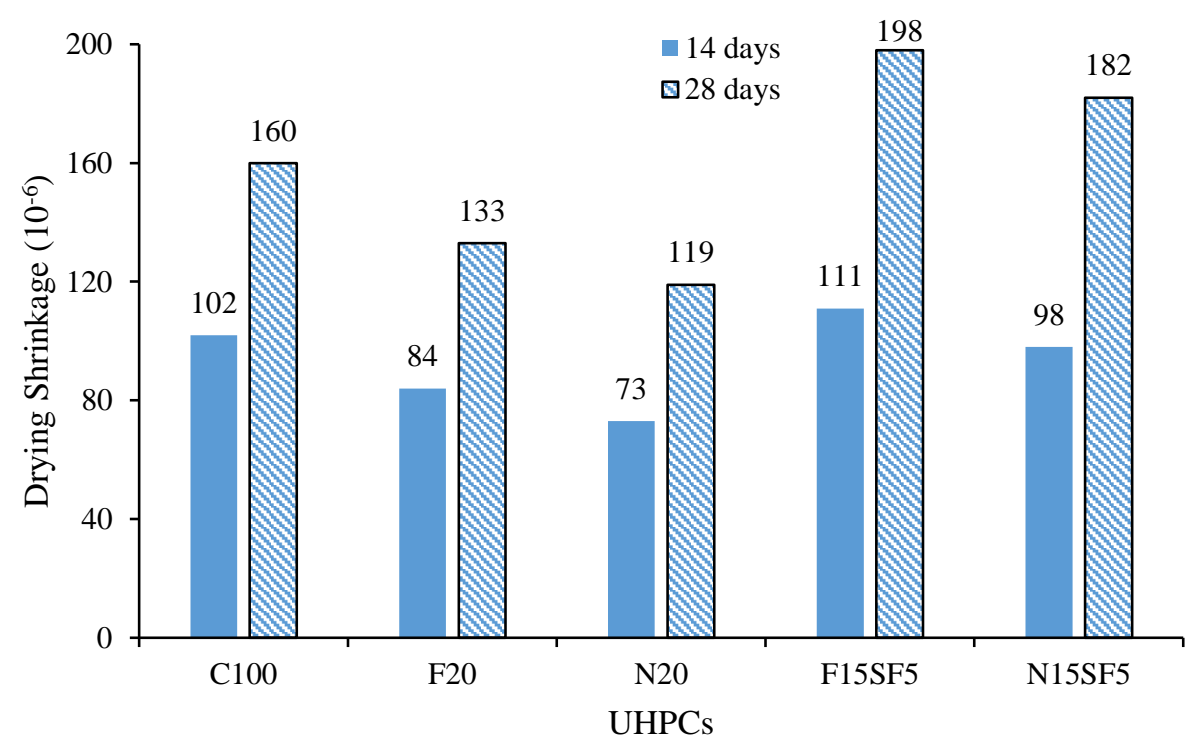

Figure 7: Drying shrinkage of the studied UHPCs

\section{CONCLUSION}

The following observations can be made from this study:

- Due to high fineness and sticky behavior, UHPCs made with silica fume required more HRWRA than did other studied mortars. Spherical shape of the Class F fly ash proved to be an advantage in getting high flow with a minimum amount of HRWRA.

- At 28 days, more than $120 \mathrm{MPa}$ compressive strength can be attained using locally available fine aggregates. Expensive quartz sand can be replaced with a locally available fine aggregate without compromising the required strength properties.

- Replacing a portion of Portland cement with fly ash and natural pozzolan seemed to be effective in achieving high compressive strength without any addition of silica fume. 
Incorporation of silica fume had a positive impact on the strength properties. However, cost of concrete increases for the UHPCs containing silica fume.

- Natural pozzolan produced lowest drying shrinkage development amongst the studied UHPCs, whereas mortars containing silica fume yielded highest drying shrinkage when compared to both natural and industrial pozzolan.

\section{ACKNOWLEDGEMENTS}

This research was funded by a grant made possible by the University Transportation Center through US Department of Transportation. Thanks are extended to a number of producers who donated materials.

\section{REFERENCES}

Aghdasi, P., Heid, A. E., \& Chao, S. H. (2016). Developing Ultra-High-Performance FiberReinforced Concrete for Large-Scale Structural Applications. ACI Materials Journal, 113(5), 559-570.

Alsalman, A., Dang, C. N., \& Hale, W. M. (2017). Development of ultra-high performance concrete with locally available materials. Construction and Building Materials, 133, 135145.

ASTM C1240-15, Standard Specification for Silica Fume Used in Cementitious Mixtures, ASTM International, West Conshohocken, PA, 2015, www.astm.org

ASTM C150 / C150M-18, Standard Specification for Portland Cement, ASTM International, West Conshohocken, PA, 2018, www.astm.org

ASTM C157 / C157M-17, Standard Test Method for Length Change of Hardened HydraulicCement Mortar and Concrete, ASTM International, West Conshohocken, PA, 2017, www.astm.org

ASTM C496 / C496M-17, Standard Test Method for Splitting Tensile Strength of Cylindrical Concrete Specimens, ASTM International, West Conshohocken, PA, 2017, www.astm.org

ASTM C618-17a, Standard Specification for Coal Fly Ash and Raw or Calcined Natural Pozzolan for Use in Concrete, ASTM International, West Conshohocken, PA, 2017, www.astm.org 
Chen, T., Gao, X., \& Ren, M. (2018). Effects of autoclave curing and fly ash on mechanical properties of ultra-high performance concrete. Construction and Building Materials, 158, 864-872.

Ibrahim, M. A., Farhat, M., Issa, M. A., \& Hasse, J. A. (2017). Effect of Material Constituents on Mechanical and Fracture Mechanics Properties of Ultra-High-Performance Concrete. ACI Materials Journal, 114(3), 453-465.

Ma, J., Orgass, M., Dehn, F., Schmidt, D., \& Tue, N. V. (2004, September). Comparative investigations on ultra-high performance concrete with and without coarse aggregates. In Proceedings of international symposium on ultra high performance concrete, Germany (pp. 205-212).

Meng, W., \& Khayat, K. (2017). Effects of saturated lightweight sand content on key characteristics of ultra-high-performance concrete. Cement and Concrete Research, 101, 4654.

Soliman, N. A., \& Tagnit-Hamou, A. (2017). Partial substitution of silica fume with fine glass powder in UHPC: Filling the micro gap. Construction and Building Materials, 139, 374-383.

Wang, C., Yang, C., Liu, F., Wan, C., \& Pu, X. (2012). Preparation of ultra-high performance concrete with common technology and materials. Cement and concrete composites, 34(4), 538-544.

Wille, K., Naaman, A. E., \& Parra-Montesinos, G. J. (2011). Ultra-High Performance Concrete with Compressive Strength Exceeding $150 \mathrm{MPa}(22 \mathrm{ksi})$ : A Simpler Way. ACI Materials Journal, 108(1), 46-54.

Yang, S. L., Millard, S. G., Soutsos, M. N., Barnett, S. J., \& Le, T. T. (2009). Influence of aggregate and curing regime on the mechanical properties of ultra-high performance fibre reinforced concrete (UHPFRC). Construction and Building Materials, 23(6), 2291-2298.

Yiğiter, H., Aydın, S., Yazıcı, H., \& Yardımcı, M. Y. (2012). Mechanical performance of low cement reactive powder concrete (LCRPC). Composites Part B: Engineering, 43(8), 29072914.

Zhao, S., Fan, J., \& Sun, W. (2014). Utilization of iron ore tailings as fine aggregate in ultra-high performance concrete. Construction and Building Materials, 50, 540-548. 